\title{
WATER EROSION IN NO-TILLAGE MONOCULTURE AND INTERCROPPED SYSTEMS ALONG CONTOUR LINES ${ }^{(1)}$
}

\author{
Ildegardis Bertol ${ }^{(2)}$, Roger Robert Ramos ${ }^{(3)}$, Fabrício Tondello Barbosa ${ }^{(4)}$, Antonio Paz \\ González $^{(5)}$, Julio César Ramos ${ }^{(3)}$ \& Douglas Henrique Bandeira ${ }^{(3)}$
}

\begin{abstract}
SUMMARY
Water erosion is the major cause of soil and water losses and the main factor of degradation of agricultural areas. The objective of this work was to quantify pluvial water erosion from an untilled soil with crop rows along the contour, in 2009 and 2010, on a Humic Dystrupept, with the following treatments: a) maize monoculture; b) soybean monoculture; c) common bean monoculture; d) intercropped maize and bean, exposed to four simulated rainfall tests of on hour at controlled intensity $\left(64 \mathrm{~mm} \mathrm{~h}^{-1}\right)$. The first test was applied 18 days after sowing and the others; 39,75 and 120 days after the first test. The crop type influenced soil loss through water erosion in the simulated rainfall tests 3 and 4; soybean was most effective in erosion control in test 3 , however, in test 4 , maize was more effective. Water loss was influenced by the crop type in test 3 only, where maize and soybean were equally effective, with less runoff than from the other crops. The soil loss rate varied during the runoff sampling period in different ways, demonstrating a positive linear relationship between soil and water loss, in the different rainfall tests.
\end{abstract}

Index terms: water losses, soil losses, simulated rainfall.

\section{RESUMO: EROSÃO HÍDRICA EM SOLO NÃO PREPARADO CULTIVADO EM CONTORNO COM USO DE SISTEMAS DE CULTIVO SOLTEIRO E EM CONSÓRCIO}

A erosão hídrica é a principal causa das perdas de solo e água, assim como de degradação das áreas agrícolas. O objetivo deste trabalho foi quantificar a erosão hídrica pluvial em uma

\footnotetext{
(1) Received to publication on September 26, 2012 and approved on January 9, 2013.

(2) Teacher, Soil Department, Santa Catarina State University - UDESC-CAV. Av. Luiz de Camões 2090. CEP 88520-000 Lages (SC), Brazil. Email: a2ib@cav.udesc.br

(3) Schoolboy, Soil Science Posgraduation, UDESC-CAV. E-mail: ramosrogerrobert@hotmail.com; julio.ramos.ta@gmail.com; douglas_ibf@hotmail.com

(4) Edafology University Professor, Coruña University, UDC. A Zapateira 15071, La Coruña, Spain. E-mail: tucho@udc.es
} 


\begin{abstract}
área sem preparo prévio do solo, cultivada em contorno, em 2009 e 2010, sobre um Cambissolo Húmico, com os seguintes tratamentos: milho solteiro, soja solteira, feijão solteiro e milho e feijão consorciados, submetidos a quatro testes de chuva simulada com intensidade constante de $64 \mathrm{~mm} \mathrm{~h}^{-1}$ e duração de $1 \mathrm{~h}$. O primeiro teste foi aplicado 18 dias após a semeadura das culturas e, os demais, 39, 75 e 120 dias, após o primeiro. O tipo de cultura influenciou a erosão hidrica nos testes 3 e 4 de chuva simulada; a soja foi mais eficaz no teste 3 , enquanto, no teste 4, o milho foi mais eficiente no controle da erosão. As perdas de água foram influenciadas pelo tipo de cultura apenas no teste 3 , onde o milho e a soja demonstraram a mesma eficiência, com menores valores de enxurrada do que as demais culturas. A taxa de perda de solo variou de distintas formas ao longo do período de amostragem da enxurrada, demonstrando relação linear positiva entre as perdas de solo e as de água, nos vários testes de chuva simulada.
\end{abstract}

Termos de indexação: perda de água, perda de solo, chuva simulada.

\section{INTRODUCTION}

Soil cover is the major factor influencing soil water erosion (Wischmeier \& Smith, 1978). Plants differ in terms of biomass, influencing soil properties and protecting the soil against erosive agents, due to the dissipation of raindrop impact energy, by canopy and crop residues, and increasing soil resistance to furrowing, by the action of their roots (Baldissera, 1985; Oliveira et al., 2003; Luciano et al., 2009).

The root and leaf type, leaf insertion angle on the stem, quantity and thickness of the stems and the plant growth habit affect water erosion by intercepting the falling raindrops. The effect of interception is well-known in management systems where the soil surface is left uncovered, for example, when the soil surface is tilled by plow and discs (Wischmeier \& Smith, 1978). However, in no-tillage systems, where crop residues are left on the soil surface, this effect is the little importance, due in part, to soil cover by the crop canopy, as a result of differences in foliar density and in canopy height above the soil (Oliveira et al., 2003; Luciano et al., 2009). On the other hand, roots of different crops does differently influence soil aggregation, as mentioned by Baldissera (1985), Cogo \& Streck (2003), Streck \& Cogo (2003) and Andrade et al. (2010). Intercropping legumes with grasses results in greater soil protection than single cropping, according to the crop performance and the sowing period (Dornelles et al., 1997; Nolla et al., 2009). Maize (Zea mays L.) has roots which are more effective in improving soil structure and its above ground part produces a large quantity of vegetative mass which intercepts the impact energy of the raindrops. Bean (Phaseolus vulgaris L.) and soybean (Glycine max L.) fix nitrogen in the soil, improving it chemically, but legume roots are less effective in soil aggregation than grass roots (Calonego \& Rosolem, 2008).

The objective of this work was to determine soil and water losses by water erosion in soybean, maize and common bean monoculture and intercropped maize - bean sown along the contour in an untilled soil, under simulated rainfall.

\section{MATERIALS AND METHODS}

The experiment was carried out in the field in 2009 and 2010, on Humic Dystrupept (Soil Survey Staff, 2010), developed from Permian siltite and argillite. The coordinates of the experimental area are $27^{\circ} 46^{\prime}$ 57" latitude South and $50^{\circ} 18^{\prime} 20^{\prime \prime}$ longitude West, at an average altitude of $900 \mathrm{~m}$ asl, with a humid, subtropical climate (Köppen Cfb).

The experimental area was initially covered by native grassland and in April 2006, the soil was tilled by plowing and three diskings. Thereafter, soil acidity was corrected by the application of $15 \mathrm{t} \mathrm{ha}^{-1}$ lime, incorporated into the soil by one plowing and two diskings. Between May and November 2006, no-tillage oats (Avena strigosa) and vetch (Vicia sativa) were grown in the area, exposed to five simulated rainfall tests between September and December 2006 (Luciano et al., 2009). Afterwards, the crop sequence in a notilled soil was: common bean, harvested in April, 2007; vetch chemically dehydrated in November 2007; followed by a bean crop, grown until April 2008. After the bean harvest, the soil was tilled with one plowing and two diskings and vetch was sown in the area again, the seeds being incorporated by light disking. The next crop sequence was bean, managed in no tillage, harvested in April 2009, followed by a mixture of vetch and oat, under no till, using a light disking to incorporate their seeds, and a roller to biomass management at the end of the cycle, in October 2009. On December 1, 2009, the experimental plots were marked and installed in untilled soil.

The plots $(3.5 \times 11 \mathrm{~m})$ in the slope direction, were bordered on the sides by galvanized plates, driven 10 $\mathrm{cm}$ deep into the soil. Runoff collection pipes were installed at the lower end of the plots, and connected by tubes, allowing passage of the flow, to a trench situated $6 \mathrm{~m}$ below, where sediment and runoff samples were collected, according to the description by Bertol et al. (1987).

Soils physical properties in the experimental area were characterized according to Embrapa (1997) methods before installing the treatments, using rings (height $5 \mathrm{~cm}$, diameter $5 \mathrm{~cm}$ ), at three randomly 
distributed points in the $0-10 \mathrm{~cm}$ layer, resulting in a soil density of $1.28 \mathrm{~kg} \mathrm{dm}^{-3}$, macroporosity of $0.12 \mathrm{~m}^{3}$ $\mathrm{m}^{-3}$, microporosity $0.39 \mathrm{~m}^{3} \mathrm{~m}^{-3}$, and total porosity of $0.51 \mathrm{~m}^{3} \mathrm{~m}^{-3}$

The treatments were installed with two replications, with a total of eight experimental units, distributed in two blocks. Immediately before sowing, 22 furrows per plot were opened along the contour lines of the terrain with a mechanical no-till seed drill machine. The crops were hand-sown in furrows recently opened with a hand-held planter, as follows: 1) maize, with row spacing of $50 \mathrm{~cm}$ and $33 \mathrm{~cm}$ between plants in the rows, with three seeds per planting hole; 2) soybean, with row spacing of $50 \mathrm{~cm}$ and $10 \mathrm{~cm}$ between plants in the rows, with three seeds per planting hole; 3 ) bean, with row spacing of $50 \mathrm{~cm}$ and $10 \mathrm{~cm}$ between plants in the rows, with three seeds per planting hole; 4) intercropped maize bean, with three rows of common bean between two rows of maize, with a row spacing of $50 \mathrm{~cm}$ for maize and bean; the spacing between plants in the rows was $33 \mathrm{~cm}$ for maize, with three seeds per planting hole, and $10 \mathrm{~cm}$ for bean with three seeds per planting hole. Common bean was harvested on February 26, 2010, i.e., seven days before rainfall test 3 , while maize and soybean were harvested after rainfall test 4 .

Four simulated rainfall tests were applied to each treatment, with five rainfalls per test, resulting in a total of 20 rainfalls, at controlled and constant intensity of $64 \mathrm{~mm} \mathrm{~h}^{-1}$ and duration of $60 \mathrm{~min}$, using a rotating-boom rainfall simulator (Swanson, 1965). The tests were applied as follows: Test 1 on December 18,2009 , i.e., 18 days after sowing (DAS); test 2: 57 DAS; test 3: 93 DAS; and test 4: 135 DAS.

During the period of simulated rainfall applications, some natural rain occurred in the experimental area. Between sowing and test 1, a total of $49 \mathrm{~mm}$ was registered in five natural rainfalls; between test 1 and test $2,199 \mathrm{~mm}$ of rain in 17 rain events; between test 2 and test 3 , a total of $190 \mathrm{~mm}$ in 16 rain events, with; and between test 3 and test 4 the total precipitation was $186 \mathrm{~mm}$ in 15 rainfalls.

Immediately before the beginning of each rain simulation, soil samples were collected from the middle of each plot (layers 0-10 and 10-20 cm) to analyze soil gravimetric water content as described by Embrapa (1997). The starting and finishing times of runoff, in relation to the beginning of the rainfall, were recorded on a worksheet. Runoff samples collection started at the beginning of surface runoff, and were repeated with a regular 5-min interval, to determine the instantaneous runoff rate and calculate soil and water losses, according to the method described by Cogo (1981). The applied rainfall intensity was monitored by 20 pluviometers distributed over the area under simulated rainfall.

The recorded soil loss data were adjusted to the average slope of the experimental plots $\left(0.134 \mathrm{~m} \mathrm{~m}^{-1}\right)$ because of the slope variation between plots $(0.124$ -
$0.145 \mathrm{~m} \mathrm{~m}^{-1}$ ) by the procedure recommended by Wischmeier \& Smith (1978), using the following equation:

$$
\begin{aligned}
& \mathrm{S}=0.065+4.56 \operatorname{sen} \theta+65.41(\mathrm{sen})^{2} \\
& \theta=\text { slope angle. }
\end{aligned}
$$

After adjusting the soil loss to the average plot slope, these data were adjusted to the planned rainfall intensity of $64 \mathrm{~mm} \mathrm{~h}^{-1}$, because of the variation in intensity between the applied rain simulations (Table 1), according to Cogo (1981). The water loss data were expressed as percentage of the simulated rainfall.

The water and soil loss results were subjected to analysis of variance and means were compared by the Duncan test (significance level $5 \%$ ). Linear regressions were adjusted between runoff starting time and soil water content before the rainfall, and between soil losses and water losses, using the model $\mathrm{y}=\mathrm{a}+\mathrm{bx}$. The relationships between soil loss rates and runoff collection times were also calculated and shown in a graph.

\section{RESULTS AND DISCUSSION}

The soil gravimetric water content prior to rainfall was, on average, $30 \%$ in the $0-10 \mathrm{~cm}$ layer and $31 \%$ in the 10-20 cm layer, with variations between rainfall tests (Table 2). The lowest water content in the 0-10 $\mathrm{cm}$ layer was $20 \%$, in rainfall test 3 on the maize treatment, which is $10 \%$ below the average content. The highest content was $38 \%$ in the soybean treatment in rainfall test 2 , i.e., $8 \%$ above than the average content. In the $10-20 \mathrm{~cm}$ layer, the lowest soil water content was $22 \%$, in the maize treatment in rainfall test 3 , i.e., $9 \%$ below the average content, while the highest value was $37 \%$ in soybean, in the rainfall tests 2 and 4, i.e., $6 \%$ higher than the average water content. Between treatments, soil water content varied only in test 3 , and was lower in maize than in the other treatments, while between tests the variation in soil moisture was more pronounced.

Table 1. Intensity and height of simulated rainfall applied for 1 hour per replication $(R)$, in different treatments in four rainfall tests

\begin{tabular}{lccccc}
\hline Treatment Replication & Test $\mathbf{1}$ & Test 2 & Test 3 & Test 4 \\
\hline \multirow{2}{*}{ Maize } & $\mathrm{R} 1$ & 63.6 & 63.2 & 59.6 & 63.8 \\
\multirow{3}{*}{ Soybean } & $\mathrm{R} 2$ & 65.7 & 63.2 & 60.7 & 63.6 \\
\multirow{3}{*}{ Bean } & $\mathrm{R} 1$ & 62.4 & 61.3 & 56.3 & 61.0 \\
& $\mathrm{R} 2$ & 80.8 & 62.6 & 64.6 & 65.7 \\
\multirow{3}{*}{ Maize/bean } & $\mathrm{R} 1$ & 63.6 & 63.2 & 59.6 & 63.8 \\
& $\mathrm{R} 2$ & 65.7 & 63.2 & 60.7 & 63.6 \\
& $\mathrm{R} 1$ & 62.4 & 61.3 & 56.3 & 61.0 \\
& $\mathrm{R} 2$ & 80.8 & 62.6 & 64.6 & 65.7 \\
\hline
\end{tabular}


Table 2. Soil gravimetric water content before simulated rainfall application on two soil layers, and time from the start of the rainfall to start the runoff, according to the different treatments and in the four rainfall tests

\begin{tabular}{|c|c|c|c|c|c|c|c|c|}
\hline \multirow[t]{3}{*}{ Treatment } & \multicolumn{2}{|c|}{ Test 1} & \multicolumn{2}{|c|}{ Test 2} & \multicolumn{2}{|c|}{ Test 3} & \multicolumn{2}{|c|}{ Test 4} \\
\hline & \multicolumn{8}{|c|}{ Soil layer $(\mathrm{cm})$} \\
\hline & $0-10$ & $10-20$ & $0-10$ & $10-20$ & $0-10$ & $10-20$ & $0-10$ & $10-20$ \\
\hline & \multicolumn{8}{|c|}{ Soil moisture (\%) } \\
\hline Maize & $27 \mathrm{aA}$ & $30 \mathrm{aA}$ & $31 \mathrm{aA}$ & $31 \mathrm{aA}$ & $20 \mathrm{bB}$ & $22 \mathrm{bB}$ & $32 \mathrm{aA}$ & $32 \mathrm{aA}$ \\
\hline Soybean & $28 \mathrm{aB}$ & $30 \mathrm{aB}$ & $38 \mathrm{aA}$ & $37 \mathrm{aA}$ & $27 \mathrm{aB}$ & $31 \mathrm{aB}$ & $35 \mathrm{aA}$ & $37 \mathrm{aA}$ \\
\hline Bean & $27 \mathrm{aA}$ & $28 \mathrm{aA}$ & $30 \mathrm{aA}$ & $31 \mathrm{aA}$ & $28 \mathrm{aA}$ & $29 \mathrm{aA}$ & $31 \mathrm{aA}$ & $33 \mathrm{aA}$ \\
\hline Maize/bean & $28 \mathrm{aB}$ & $32 \mathrm{aAB}$ & $33 \mathrm{aAB}$ & $35 \mathrm{aA}$ & $27 \mathrm{aB}$ & $28 \mathrm{aB}$ & $36 \mathrm{aA}$ & $36 \mathrm{aA}$ \\
\hline \multicolumn{9}{|c|}{$\mathrm{CV}($ of treatments in each test, for $0-10 \mathrm{~cm})=5 \%$} \\
\hline \multicolumn{9}{|c|}{$\mathrm{CV}$ (of tests in each treatment, for $0-10 \mathrm{~cm}$ ) $=3 \%$} \\
\hline \multicolumn{9}{|c|}{$\mathrm{CV}($ of treatments in each test, for $10-20 \mathrm{~cm})=4 \%$} \\
\hline \multicolumn{9}{|c|}{$\mathrm{CV}$ (of tests in each treatment, for $10-20 \mathrm{~cm})=3 \%$} \\
\hline & \multicolumn{8}{|c|}{ Time start runoff (min) } \\
\hline Maize & \multicolumn{2}{|c|}{$38 \mathrm{aA}$} & \multicolumn{2}{|c|}{$23 \mathrm{aB}$} & \multicolumn{2}{|c|}{$45 \mathrm{aA}$} & \multicolumn{2}{|c|}{$13 \mathrm{aC}$} \\
\hline Soybean & \multicolumn{2}{|c|}{$35 \mathrm{aA}$} & \multicolumn{2}{|c|}{$20 \mathrm{aB}$} & \multicolumn{2}{|c|}{$50 \mathrm{aA}$} & \multicolumn{2}{|c|}{$13 \mathrm{aC}$} \\
\hline Bean & \multicolumn{2}{|c|}{$38 \mathrm{aA}$} & \multicolumn{2}{|c|}{$23 \mathrm{aB}$} & \multicolumn{2}{|c|}{$43 \mathrm{aA}$} & \multicolumn{2}{|c|}{$10 \mathrm{aC}$} \\
\hline Maize/bean & \multicolumn{2}{|c|}{$38 \mathrm{aA}$} & \multicolumn{2}{|c|}{$20 \mathrm{aB}$} & \multicolumn{2}{|c|}{$43 \mathrm{aA}$} & \multicolumn{2}{|c|}{$13 \mathrm{aC}$} \\
\hline \multicolumn{9}{|c|}{$\mathrm{CV}($ of treatments in each test $)=8 \%$} \\
\hline CV (of tests & reatmen & & & & & & & \\
\hline
\end{tabular}

CV: coefficient of variation. Capital letters compare rainfall tests in each treatment, and small letters compare treatments in each rainfall test $(\mathrm{p}<0.05)$.

The variation in soil water content between rainfall tests (Table 2), was normal, according to the crop type of each treatment, as shown by Luciano et al. (2009). Each plant type protects the soil in a different manner and absorbs different quantities of water from it, which vary over time according to the growth rate. The temporary variations in soil water content were also influenced by climatic variations that occurred in the experimental period. The variation between rainfall tests was also influenced by the soil spatial variation although all treatments were included in the same soil texture class. These variations were also reported in experiments carried out by Barbosa et al. (2012), working with a typical clayey Alfisol. It is therefore important to remember that this variation in soil water content before the simulated rainfall application can influence the study variables, especially water loss by runoff.

The time from the beginning of runoff is an important hydraulic variable, with influences on soil water infiltration rate, runoff volume, and runoff peaks rate, as described by Bertol et al. (2008). The times until runoff began varied greatly between the rainfall tests, with lower variation between treatments (Table 2 ). Between tests, this period ranged was from 12 to $45 \mathrm{~min}$, in the average of treatments, while between treatments, the variation was from 26 to $31 \mathrm{~min}$, in the average of the tests. This can be at least partially explained by the effect of the previous soil water content, influencing similarly the time until onset of runoff, according to Luciano et al. (2009) and Barbosa et al. (2012).

The relationship between data of runoff starting time and soil water content before rainfall application is shown in figures 1 and 2. Despite the data dispersion in these figures, the relationship between variables was significant at $5 \%$, in both soil layers. So, the higher the soil water content, the shorter the time until runoff began after the rain had started. In the case of the data of the $10-20 \mathrm{~cm}$ layer, $28 \%$ of the runoff start time was explained by the soil water content (Figure 1), while for the $0-10 \mathrm{~cm}$ layer, this relation was $36 \%$ (Figure 2). This information is important because soil water content prior to rainfall application varies according to the interval between tests, and influences water erosion, as shown by Panachuki et al. (2011).

Water losses by runoff, according to the applied rainfall volume (Table 3), were very low in some cases, e.g., in test 3 of maize and soybean, but very high in others, e.g., in test 4 in all treatments. These values were similar to those reported by Panachuki et al. (2011). This can be partly explained by the different volume of rainfall per plot, according to the rain intensity (Table 1).

The variation between water losses (Table 3) was also influenced by soil water content before rainfall application (Table 2), in agreement with results from other studies (Cogo, 1981; Panachucki et al., 2011; 
Barbosa et al., 2012). The high runoff intensity in some treatments and, especially, at the end of the crop cycles (rainfall test 4 ), were related to the critical rainfall events. This indicates the need for mechanical structures to control runoff under these conditions, as suggested by Barbosa et al. (2012). In other words, the problem of water erosion is directly related to the occurence of excess rainfall, which is also possible in areas under no tillage. Even though

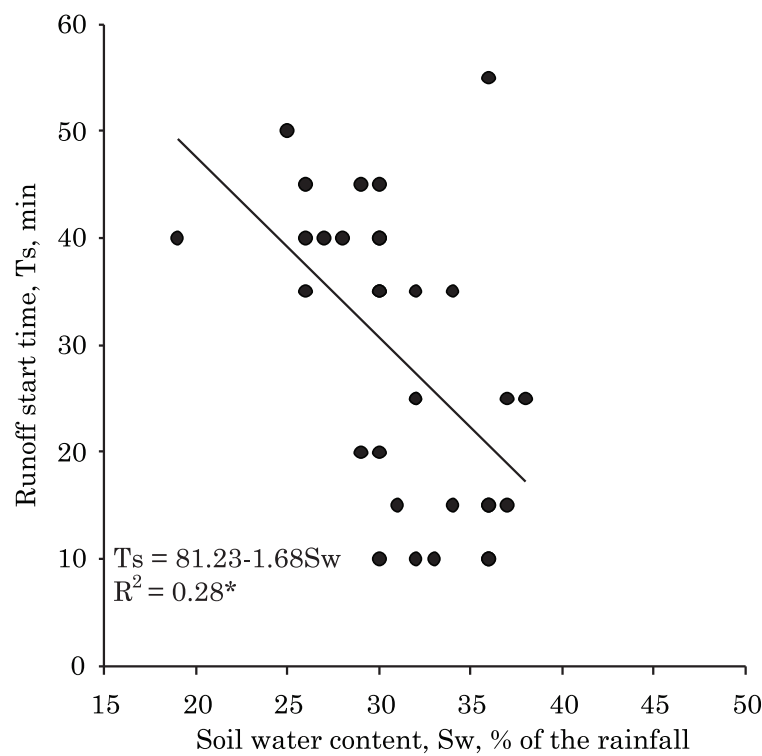

Figure 1. Relationship between runoff starting time (Ts) and soil water content before the rainfall, $\mathrm{Sw}$, in the 10-20 $\mathrm{cm}$ layer, considering all treatments and rainfall tests $(n=32)$.

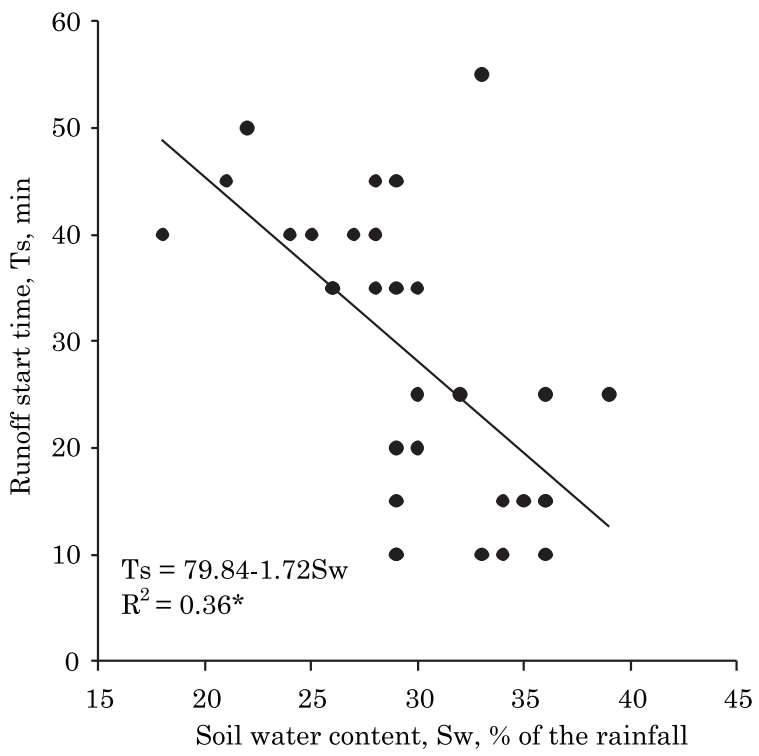

Figure 2. Relationship between runoff starting time $(\mathrm{Ts})$ and soil water content before rainfall, $\mathrm{Sw}$, in the 0-10 cm layer, considering all treatments and rainfall tests $(n=32)$. there were no statistical differences in the soil loss data in most cases, related to management treatments, the effect of crop on water losses must be taken into account to calculate and adjust structures to runoff control, e.g., terraces. Different plant species can influence rainwater interception by their canopies, and improve soil structure and create biopores by their roots.

Soil losses varied from $9.0 \mathrm{~kg} \mathrm{ha}^{-1}$, a value considered low, to $608.9 \mathrm{~kg} \mathrm{ha}^{-1}$, considered high (Table 3 ), depending on the rainfall applied, and the crop treatment. Soil loss was lowest from the soybean treatment during rainfall test 3 . In this test, the crop was in full vegetative development, protecting the soil against erosion. Therefore, runoff set in after $40 \mathrm{~min}$ rainfall and the soil loss rate was approximatley 25 $\mathrm{kg} \mathrm{ha}^{-1} \mathrm{~h}^{-1}$ after $50 \mathrm{~min}$ rainfall (Figure 3). The greatest soil loss, on the other hand, occured in the common bean treatment during rainfall test 4 . In this test, the crop had already been harvested (it had been harvested before test 3 ) and, therefore, no vegetation protected the soil against erosion at this time. Therefore, runoff began after only 5 min rainfall and the soil loss rate was approximately $750 \mathrm{~kg} \mathrm{ha}^{-1} \mathrm{~h}^{-1}$ after 10 min rainfall.

Over the course of the rainfall tests which were applied during the crop cycle, the soil losses sometimes increased, decreased, remained stable or oscillated, independently of the water loss (Table 3 ), according to Bertol et al. (2010). This erratic soil loss data behaviour is normal, in agreement with the variation in sediment concentration in the runoff (data not presented here), as also shown by Bertol et al. (1997), Luciano et al. (2009) and Gobbi et al. (2011).

Considering the total soil loss during the crop cycle (Table 3), the bean crop was the least and maize the most effective, with a loss from maize of $31 \%$ of loss from common bean. The lower effect of bean in erosion control was also observed for maize/bean intercrop, with soil loss 2.6 times higher than from maize monoculture. The lower effectiveness of bean in relation to maize for water erosion control can be explained by the different morphologies of the crops, in the aerial part of the plant as much as in the roots, according to Oliveira et al. (2003). The shorter cycle of bean than maize also explains this result. At the time of rainfall test 3 , common bean had already been harvested while the maize plants were still protecting the soil.

The distribution of the soil loss rate in the runoff sampling period, throughout the simulated rainfall applications (Figure 3), can be considered normal and contributed partly to explain the total soil loss. In all rainfall tests and treatments, the soil loss rates were low at the start of runoff, increasing later. In test 1 and 3 , there was practically no stability in the values with two exceptions, due to the short sampling period (25 $\mathrm{min}$ ), while in test 2 and 4 , in practically all 


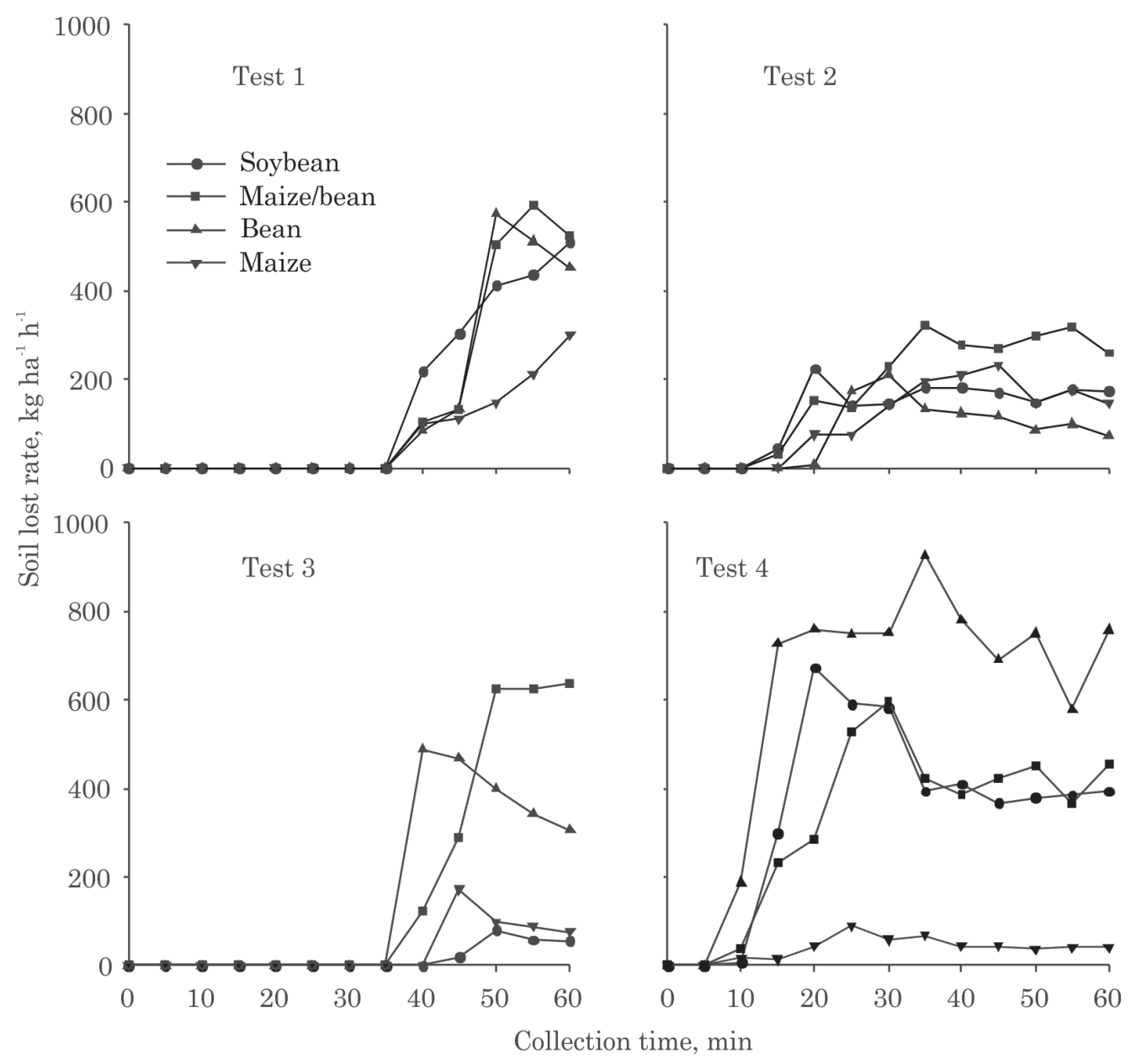

Figure 3. Evolution of instantaneous soil loss rate during the runoff sampling period in crop treatments under smulated rainfall (average of two replications). Legend applies to all four graphs.

Table 3. Water losses adjusted to planned rainfall intensity and soil losses adjusted to the terrain slope and to the planned rainfall intensity, in each treatment and rainfall test (average of replications)

\begin{tabular}{|c|c|c|c|c|c|}
\hline Treatment & Test 1 & Test 2 & Test 3 & Test 4 & Total \\
\hline & \multicolumn{5}{|c|}{ Water loss (\% of rainfall) } \\
\hline Maize & $10.4 \mathrm{aB}$ & $37.9 \mathrm{aA}$ & $4.7 \mathrm{bB}$ & $54.7 \mathrm{aA}$ & 26.9 a \\
\hline Soybean & $25.0 \mathrm{aB}$ & $44.2 \mathrm{aAB}$ & $3.4 \mathrm{bC}$ & $64.4 \mathrm{aA}$ & $34.3 \mathrm{a}$ \\
\hline Bean & $17.2 \mathrm{aB}$ & $39.2 \mathrm{aAB}$ & $2.5 \mathrm{bB}$ & $78.2 \mathrm{aA}$ & $38.8 \mathrm{a}$ \\
\hline Maize/bean & $19.8 \mathrm{aBC}$ & $41.2 \mathrm{aAB}$ & $15.9 \mathrm{aC}$ & $66.6 \mathrm{aA}$ & 35.9 a \\
\hline \multicolumn{6}{|c|}{$\mathrm{CV}$ (of treatments in each test) $=16.7 \%$} \\
\hline \multicolumn{6}{|c|}{$\mathrm{CV}($ of tests in each treatment $)=12.5 \%$} \\
\hline \multicolumn{6}{|c|}{ Soil loss $\left(\mathrm{kg} \mathrm{ha}^{-1}\right)$} \\
\hline Maize & $83.4 \mathrm{aA}$ & $119.0 \mathrm{aA}$ & $65.2 \mathrm{aA}$ & $44.0 \mathrm{bA}$ & $311.7 \mathrm{~d}$ \\
\hline Soybean & $133.5 \mathrm{aA}$ & $117.1 \mathrm{aA}$ & $9.0 \mathrm{bB}$ & 339.9 aA & $599.5 \mathrm{c}$ \\
\hline Bean & $160.0 \mathrm{aAB}$ & $86.7 \mathrm{aC}$ & $146.0 \mathrm{aB}$ & $609.0 \mathrm{aA}$ & $1,001.7 \mathrm{a}$ \\
\hline Maize/bean & $159.1 \mathrm{aA}$ & $159.6 \mathrm{aA}$ & $190.2 \mathrm{aA}$ & $307.0 \mathrm{aA}$ & $816.0 \mathrm{~b}$ \\
\hline \multicolumn{6}{|c|}{$\mathrm{CV}$ (of treatments in each test) $=12.6 \%$} \\
\hline $\mathrm{CV}$ (of tests $\mathrm{i}$ & t) $=13.5 \%$ & & & & \\
\hline
\end{tabular}

CV: coefficient of variation. Capital letters compare rainfall tests in each treatment, and small letters compare treatments in each rainfall test $(p<0.05)$. 
treatments, the soil loss rate stabilized after $25 \mathrm{~min}$, due to the longer sampling period. In test 3 , soil loss was low from maize and soybean (Table 3 ). This can be explained by the delay in the start of runoff ( 40 min) which led to low water loss and low soil loss rates throughout the sampling period (Figure 3). In test 4, on the other hand, soil losses from bean, maize/ bean intercrop and soybean were high. This was explained by the early onset of runoff ( $5 \mathrm{~min}$ ), resulting in high water soil loss rates throughout the collection period.

Soil losses have a significant, positive and linear relationship with water loss (Figure 4). The data dispersion indicates that some low water losses were related to high soil loss values, while some high water loss values resulted in low soil loss rates. This type of relationship between soil and water loss is normal, especially in soil management systems without mechanical soil tillage and where no plant residues were removed by the runoff. This occurs because, as the volume of water in the runoff increases, the runoff velocity also increases and consequently so does the breakdown energy and sediment transport (Bertol et al., 1997; Barbosa et al., 2012). The slope of the curve is determined by the soil type, amount and type of crop residue on the soil surface, type and form of crop management, characteristics of rainfall and soil water content prior to rainfall (Cogo, 1981; Luciano et al., 2009; Barbosa et al., 2012), among other factors. In this work, this positive and linear relation between soil and water losses (Figure 4) resulted mainly of the crop type and soil water variation, independently of the rainfall tests.

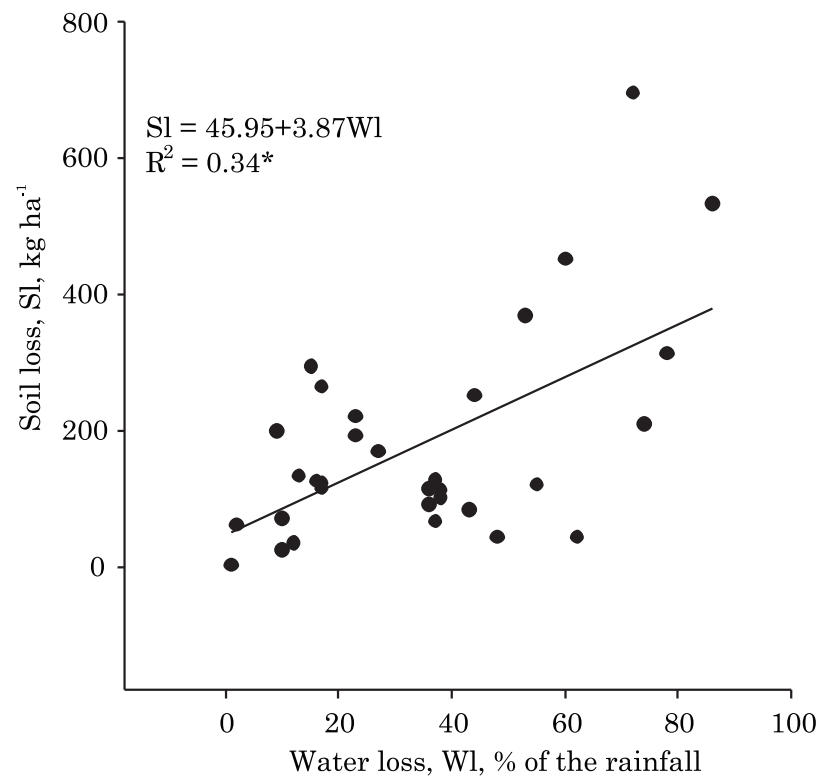

Figure 4. Relationship between soil loss (SI) and water loss (Wl), considering all treatments with soil cultivation and rainfall tests $(n=32)$.

\section{CONCLUSIONS}

1. The soil gravimetric water content before the rainfall varied between rainfall tests, in some cases, in both soil layers, and between treatments only in test 3 . The time interval between the beginning of rainfall and the beginning of runoff, was longer in test 1 and 3 , shorter in test 4 and was intermediate in test 2 , with no statistical variation among treatments.

2 . The crop type influenced soil losses, caused by water erosion, in the rainfall tests 3 and 4; soybean was more effective in test 3 and maize in test 4 ; water losses were influenced by crop type in test 3 only, in which maize and soybean were equally effective, with less runoff than from the other crops.

3 . The soil loss rate varied over the runoff sampling period in distinct ways in the different simulated rainfall tests; the relationship between soil loss and water loss was linear and positive.

\section{LITERATURE CITED}

ANDRADE, A.P.; MAFRA, A.L; BALDO, G.R.; PÍCOLLA, C.D.; BERTOL, I. \& ALBUQUERQUE, J.A. Physical properties of a humic Cambisol under tillage and cropping systems after 12 years. R. Bras. Ci. Solo, $34: 219-226,2010$.

BALDISSERA, I.T. Condições físicas de um solo Terra Roxa Estruturada distrófica na encosta basáltica do Rio Grande do Sul sob diferentes usos. Porto Alegre, Universidade Federal do Rio Grande do Sul, 1985. 89p. (Dissertação de Mestrado)

BARBOSA, F.T.; BERTOL, I.; WERNER, R.S.; RAMOS, J.C. \& RAMOS, R.R. Comprimento crítico de declive relacionado à erosão hídrica, em três tipos e doses de resíduos em duas direções de semeadura direta. R. Bras. Ci. Solo, 36:1279-1290, 2012.

BERTOL, I.; BARBOSA, F.T.; FABIAN, E.L.; PEGORARO, R.; ZAVASCHI, E.; PAZ GONZÁLEZ, A. \& VIDAL VÁZQUEZ, E. Escoamento superficial em diferentes sistemas de manejo em um Nitossolo Háplico típico. R. Bras. Eng. Agríc. Amb., 12:243-250, 2008.

BERTOL, I.; COGO, N.P. \& LEVIEN, R. Relações da erosão hídrica com métodos de prepare do solo, na ausência e na presença de cobertura por resíduo cultural de trigo. R. Bras. Ci. Solo, 11:187-192, 1987.

BERTOL, I.; COGO, N.P. \& MIQUELLUTI, D.J. Sedimentos transportados pela enxurrada relacionados á cobertura e rugosidade superficial do solo e taxa de descarga. Pesq. Agropec. Gaúcha, 3:199-206, 1997.

BERTOL, I.; ZOLDAN JUNIOR, W.A.; PAZ GONZÁLEZ, A.; BARBOSA, F.T. \& WERNER, R.S. Sediment transport in runoff on rugous soil surface submited to simulated rainfall. Sci. Agríc., 67:591-597, 2010. 
COGO, N.P. Effect of residue cover, tillage-induced roughness and slope lenght on erosion and related parameters. West Lafayette, Purdue University, 1981. 346p. (Tese de Doutorado)

COGO, N.P. \& STRECK, E.V. Surface and subsurface decomposition of a desiccated grass pasture biomass related to erosion and its prediction with RUSLE. R. Bras. Ci. Solo, 27:153-164, 2003.

CALONEGO, J.C. \& ROSOlEN, C.A. Estabilidade de agregados do solo após manejo com rotações de culturas e escarificação. R. Bras. Ci. Solo, 32:1399-1407, 2008.

DORNELLES, E.L.B.; MENDEZ, M.G.; CORRÊA, L.A.V. \& SCHUCH, L.O.B. Arranjos de plantas e épocas de semeadura no cultivo consorciado de feijão (Phaseolus vulgaris L.) e milho (Zea mays L.) na região sul do Rio Grande do Sul. R. Bras. Agroc., 3:11-16, 1997.

EMPRESA BRASILEIRA DE PESQUISA AGROPECUÁRIA EMBRAPA. Manual de métodos de análise de solo. Rio de Janeiro, Embrapa Solos, 1997. 212p.

GOBBI, E.; BERTOL, I.; BARBOSA, F.T.; WERNER, R.S.; RAMOS, R.R.; PAZ-FERREIRO, J. \& GEBLER, L. Erosão hídrica associada a algumas variáveis hidrológicas em pomar de maçã submetido a diferentes manejos do solo. R. Bras. Ci. Solo, 35:1013-1024, 2011.

LUCIANO, R.V.; BERTOL, I.; BARBOSA, F.T.; VIDAL VÁZQUEZ, E. \& FABIAN, E.L. Perdas de água e solo por erosão hídrica em duas direções de semeadura de aveia e ervilhaca. R. Bras. Ci. Solo, 33:669-676, 2009.
NOLLA, A.; JUCKSCH, I. \& ALVARENGA, R.C. Cobertura do solo proporcionada pelo cultivo consorciado de milho com leguminosas e espécies espontâneas. Cultivando Saber, 2:151-163, 2009.

OLIVEIRA, T.K.; CARVALHO, G.J.; MORAES, R.N.S. \& JERÔNIMO JÚNIOR, P.R.M. Características agronômicas e produção de fitomassa de milho verde em monocultivo e consorciado com leguminosas. Ci. Agrotec., 27:223-227, 2003.

PANACHUKI, E.; BERTOL, I.; SOBRINHO, T.A.; OLIVEIRA, P.T.S. \& RIDRIGUES, D.B.B. Perdas de solo e de água e infiltração de água em Latossolo Vermelho sob diferentes sistemas de manejo. R. Bras. Ci. Solo, 35:1777$1785,2011$.

SOIL SURVEY STAFF. Soil taxonomy. A basic system of soil classification for making and interpreting soil surveys. 9.ed. Washington, USDA/SCS, 2010. 338p. (Handbook, 436)

STRECK, E.V. \& COGO, N.P. Reconsolidation of the soil surface after tillage discontinuity, with and without cultivation, related to erosion and its prediction with RUSLE. R. Bras. Ci. Solo, 27:141-151, 2003.

SWANSON, N.P. A rotating-boom rainfall simulator. Trans. Am. Soc. Agric. Eng., 26:1738-1743, 1965.

WISCHMEIER, W.H. \& SMITH, D.D. Predicting rainfall erosion losses: A guide to conservation planning. Washington, USDA, 1978. 58p. (Agricultural Handbook, 537) 